\title{
THE CONSTITUTIONAL PROBLEM OF WORKMEN'S COMPENSATION
}

\author{
By William Draper Lewis, Ph.D.,
}

Dean of the Law School, University of Pennsylvania, Philadelphia.

The Court of Appeals in New York has just rendered a decision declaring unconstitutional the Workmen's Compensation Act in that state, the ground of the decision being that the act deprives employers of their property without due process of law. The action of the highest court of the first state in the Union shows the serious nature of the constitutional problem involved in any attempt to meet present conditions by a compensation act, or in other words, by an act which throws in whole or in part on the owners of the business the financial loss resulting from all accidents to employees occurring in the course of the business and incident thereto.

The constitutional limitation that a person cannot be deprived of his life, liberty or property without due process of law, is not only in the Federal Constitution as a limitation on federal and state action, but in one form or another is found in practically all our state constitutions. On the other hand, the decision of one court on a particular act, even though, as in this case, the language of the court is sweeping enough to condemn all similar legislation, is very far from being conclusive of the question of constitutionality. If a decision on a new and important question of constitutional law is fundamentally sound, it lasts; if unsound, while it may not be formally overruled, it comes in time to be practically disregarded. Indeed, if this were not true, our written constitutions would rapidly become intolerable fetters upon the expression of the reasonable desires of the people. The famous decision of the New York Court of Appeals in 1885 , that an act which prohibited the manufacture of tobacco in tenement houses was unconstitutional, because it had no relation to the promotion of public health, and, therefore, arbitrarily deprived the owners of such houses of a reasonable use of their property, would probably not now be followed by any court, except possibly the court which decided it, because to-day courts would recognize that the legislature of New 
York was right and the Court of Appeals wrong, not on a matter of law, but on a matter of fact,-the use of tenement houses for the manufacture of tobacco being, as a matter of fact, peculiarly deleterious to health. (The matter of Jacobs, 98 New York, 98.) In the Bake-Shop Case-a decision of the Supreme Court of the United States (Lochner vs. New York, 198 U. S. 45),an act of the State of New York limiting the hours of the laborers in bakeries to sixty per week was declared unconstitutional as arbitrarily depriving the workmen of their right to contract. This case was supposed to threaten all legislation designed to limit the hours of labor, except peculiarly exhausting employments. But to-day, since the decision of the same court in the Oregon case (Muller vs. Oregon, 208 U. S. 4I2), the Bake-Shop Case is believed to stand merely for the proposition that legislation limiting the hours of labor must be shown to be reasonably designed to protect the health of the laborer.

There are grounds for believing that the constitutional prohibition against depriving persons of life, liberty or property without due process of law, as originally used in the fifth amendment of the Federal Constitution, limited merely arbitrary executive action, and perhaps legislation establishing arbitrary modes of legal procedure; but as used in the fourteenth amendment and in the state constitutions as a prohibition on state legislation it has been definitely decided to extend far beyond this, and to limit arbitrary legislation of any kind, whether affecting procedure or substantive right. In short, as a result of this provision in our constitutions, the system of law under which we live is practically this: The legislature has a wide discretion to change the law and enact new law; but the sphere of this discretion has limits; legislation that affects private rights and which shocks existing conceptions of what is fundamentally fair and right is not within the power of a legislature to enact; such legislation deprives persons of their liberty and property without due process of law, and the courts are, when a case is presented to them, the sole and only judges of what is or is not contrary to "fundamental conceptions of fairness and right." This system is peculiar to the United States. There is much to be said for and much to be said against it. I do not wish to discuss that broad question. For us, it is only presently important to recognize clearly that as a result of the system the task of the lawyer called 
upon to defend any novel legislation is to convince the court that the legislature has not so far exceeded an admittedly wide discretion, as to produce an arbitrary interference with current fundamental conceptions of right. It follows, therefore, that the task of supporting such a sweeping innovation of the law as a workmen's compensation act becomes impossible, unless the lawyers in charge of the defense of the legislation can show that the act is consistent throughout with a theory which is not, as a theory, necessarily revolting to men accustomed to mix, as our judges are to some extent, with all classes, but more especially with the educated well-to-do.

The result of the recent litigation in New York shows the difficulty of supporting a workmen's compensation act unless those especially interested have, in their own minds, carefully worked out a theory justifying the legislation. The principal innovation in the law created by any such act is that it imposes liability on the employer where he is without fault, and where he exercises every possible degree of care. When such legislation is proposed or defended, those who advocate it must be prepared to answer the objection, that the legislation is merely a scheme for arbitrarily transferring money from the pockets of the most convenient rich manthe employer-to the pockets of the injured employee; and that it is therefore grossly arbitrary, unfair and unconstitutional. It was, I think, most unfortunate that the New York act was limited to workmen engaged in dangerous employments, because this limitation suggested a reply to the objection just stated that is wholly inadequate. It was argued that the act was merely an ordinary exercise of the police power over dangerous occupations; the argument being, that if an occupation was dangerous, under the police power it could be stopped entirely, and therefore, any regulation, however arbitrary, was within the power of the legislation to enact. The premise on which this argument is based is more than doubtful. For instance, the act was made to apply to work on scaffolds more than twenty feet from the ground; yet an act which prohibited the erection of such scaffolds would without doubt be held to be unconstitutional as an arbitrary limitation on the use of property. Again, if the act was designed to lessen accidents or improve the conditions under which dangerous work could be carried on, why was the employer made liable for all accidents occurring in the 
course of the business, whether due to its dangerous character or not? Lastly, if the dangerous character of the employment and the reduction of accident is the justification for the legislation, what is the justification for making the employer liable when he is doing everything anyone could do to make the conditions safe, and the workman himself is negligent?

The report of the Wainwright Commission which drafted the New York act, while containing much valuable information, and an excellent indictment of the present system, cannot be said to contain a complete justification for the particular remedy embodied in the act. After reciting the evils of the present system, the commission in its report to the legislature, states that the evils of the present system can be "best avoided by compelling the employer to share the accident burden in intrinsically dangerous trades, since by fixing the price of his product, the shock of the accident may be borne by the community." By the community is here evidently meant the consumers of the product. But, while the ability of the owners of the business to transfer the share of the burden of industrial accidents placed upon them on the consumer is indicated, there is no explanation of why the burden should be ultimately borne by the consumer of a product, and therefore no adequate reason for selecting the employer, even though he is the only medium for distributing the shock.

Is there then any adequate answer to the objection that the New York act and all similar legislation are grossly arbitrary and therefore unconstitutional?

In order to answer this question it is first necessary to understand exactly what a workmen's compensation act does. It provides that one of the costs of the business, the loss resulting from injury to employees, should hereafter, to a certain extent, be borne by the owner and controller of the business. The law is not a police regulation of dangerous occupations. It is a law regulating business association contracts between employer and employee. A law which merely said that anyone who employed another in his business, should, unless he stipulated to the contrary, be presumed to have contracted to pay that other for all injuries resulting from the operation of the business, would be constitutional; but the ability to "contract out" would make it largely useless. The real question then in a workmen's compensation act is this: What is the justi- 
fication for saying to an employer and employee, if you contract you must contract on the basis of the employer being liable in whole or in part (as the act may designate), for injuries occurring to the employee in the prosecution of the business? Any act, dealing with a class of transactions which merely changes the presumptions of fact in regard to obligations assumed, where the obligation is not touched on by express contract, is constitutional ; but any act which goes further and interferes with the complete freedom of contract must have a reasonable theory to justify the interference, or the courts will say, and rightly, that it interferes with the fundamental right to freedom of contract of the persons affected. The problem of finding this reason is not a legal problem but an economic one. The judges are not economists. It is not for them to invent economic reasons to justify legislation.

The economic justification of a workmen's compensation act will be found on investigation to be the same as the economic justification for laws against monopoly. Laws against monopoly interfere with the freedom of contract, where that freedom is exercised to produce monopoly; yet their constitutionality has always been sustained. We have come to recognize that the monopoly by one set of men of any product or service is a bad thing for the community. When a monopoly exists, the producers, that is the persons who have the monopoly, have the practical power to exact from the consumers more than a reasonable cost of production and a fair return on the investment. The holder of a monopoly is able to get part of the product of the labor of somebody else for nothing. The reason why laws against monopoly, though they invariably interfere with the freedom of contract, have never been declared unconstitutional, is the general recognition of the fundamental economic law, that it is disastrous to the state to have the consumers of a particular product pay more than the cost of production and a fair profit, and that contracts tending to produce this result can be prohibited.

In this justification for statutes interfering with the freedom of the contract where the contract produces monopoly, we have, I believe, as stated, the justification for a workmen's compensation act. The accidents which occur from time to time to the machinery used in business, have long been regarded as one of the elements which enter into the cost of production. We have only recently awak- 
ened to the fact that another cost of production, is the loss of earning power entailed by accidents to persons engaged in the business, due to the operation of the business. This cost at present is borne largely by the workmen. It is not a part of the employer's cost, except in the case of his negligence. It is, therefore, not part of the cost of production, which is transferred in the price of the finished article to the consumer. The injustice of the present system is not that the employer does not pay for the result of injuries to his workmen. Competition among employers cuts down the employer's profit to a business return on his investment. The injustice lies in the fact that the consumer of the finished product, or the user of the service which the business supplies, is not paying for all the elements which make up the cost of that which he is getting. The consumer is here in a position analogous to the position of the monopolist. $\mathrm{He}$ is reaping an unfair advantage. $\mathrm{He}$ is getting some part of the product of another's labor without paying the full cost. If it is sound that the consumer of any article should not bear more than the cost of production and a profit, it is equally sound that to have the consumer pay only a part of the cost of the finished product, the rest of the cost being borne by one or all of the classes who have joined in its production, is an equally bad condition. Whether we should throw the burden of an accident in a particular business on the business in which it occurs, or distribute the burden by an insurance system supported by all those engaged in a similar business, is a matter of detail, provided we recognize the fact that any industrial system which does not, in effect, throw every element of cost on the consumer of the finished product, is a system that is as radically defective as one which, in effect, by permitting monopoly of production to exist, throws on the consumer more than the cost of production. Monopoly raises a class above its deserts, taking a little from each of the many to support the few. Our present system of dealing with industrial accidents is a system by which the many take from the dependent classes more than they give in return. Monopoly inflates those already economically strong; our present industrial accident law and its administration depresses those already economically weak. The fundamental vice is the same in both-an unfair price paid by the consumer; unfair because too high, or unfair because too low. Having thus justified, from an economic point of view, placing 
the burden of industrial accidents on the consumer, it merely remains to refer again to the obvious fact pointed out by the Wainwright Commission in its report, that the owner and controller of the business is the only medium through which the burden of the cost of these accidents can be placed on the consumer. The owner of the business owns the completed product and all elements of cost to him he may transfer to the consumer in the price of the product.

The justification for saying to an employer and employee, if you contract you must contract on the basis of the employers assuming the burden of industrial accident, is thus seen to be, as stated, economically the same as the justification of legislation which prohibits a contract creating a monopoly. There is, however, this difference between a contract of an employer and employee, in which the employer does not assume the financial burden of accidents incident to the operation of his business, and a contract creating a monopoly. The latter contract creates a condition which renders the oppressed parties, the consumers, helpless. They must have the article, and to have it they must pay an exorbitant price. The oppressed party, where the contract is between the employer and employee, is the employee-one of the parties to the contract. To uphold the constitutionality of any legislation which prohibits the employer making a certain contract with his employee, on the ground that the result of the contract is an unfair oppression of the employee from an economic point of view, it must not only be shown that economically the contract is unfair, but it should also be shown that the employees are so dependent that they are not in a position to refuse to enter into the contract. That a contract is unfair to one party from an economic and social standpoint, is probably not sufficient to enable the legislature to interfere; where the unfairness is to one of the parties to the contract and not to third persons. As indicated, in such a case it must also be shown that the parties on whom it bears unfairly, are in a position where they practically have to accept the unfair contract. As an illustration: The payments of miners' wages in store orders is regarded by many persons as a condition tending to depress the miner and therefore economically unfair to him. A law prohibiting such a contract was, in I886, declared unconstitutional by the Supreme Court of Pennsylvania, as an undue interference with the freedom of contract (Godcharles 
ws. Wigeman, II3 $\mathrm{Pa} .43 \mathrm{I}$ ); the laborer being regarded by the court as able to take care of himself. An opposite conclusion was reached by the Supreme Court of the United States in the case of the Knoxville Iron Company ws. Harbison (I83 U. S. I3), a case decided in Igor. Though the language of the two courts indicates, apparently, a wide divergence in attitude towards such legislation, fundamentally the difference would appear to be in the apprehension of what were the true facts, rather than a difference in the principle; the Supreme Court realized what the court of Pennsylvania as then constituted failed to realize, that the laborers were not economically strong enough to insist on payment in money. If, therefore, workmen engaged in manual labor are not, as a matter of fact, usually strong enough--and I think this can be shownto refuse work unless the employer assumes the risk of accidents in the business, and it is fundamentally fair for the reasons given that the employer should assume this risk, then a workmen's compensation act with a clause against contracting out, applicable to the more dependent classes of workmen, that is to those engaged in manual pursuits, is constitutional. It is constitutional, even though it interferes with the freedom of contract for the same fundamental reason that laws prohibiting monopolies are constitutional, though they also interfere with the same freedom.

In this paper I have tried to show that the constitutional problem in a workmen's compensation act is the problem of showing that such an act is not fundamentally unfair to the employer, according to current conceptions of fundamental right, and that, therefore, the first thing to do is to find out whether there is a correct economic basis for the legislation. If this basis cannot be found, then the legislation will be, and should be, declared unconstitutional. I have also tried to point out what I believe to be the economic reason which justifies such legislation. But in spite of confidence in the correctness of the economic position taken, I would not be fair to myself if I left you with the impression that the proof of the reasonableness of the legislation from an economic point of view removed all difficulty. It usually does in such cases where the court is convinced of the facts on which the economic argument is based, and on the soundness of the argument. But in the path of a workmen's compensation act, where liability is imposed on the owner of the particular business in which the 
accident occurred, another objection is to be met and overcome. There is more or less prevalent among the members of the legal profession, and therefore, of course among our judges, an idea that the common law never imposes liability without fault; and that consequently, any legislation which imposes liability where there is no fault, is arbitrary, unfair, and therefore unconstitutional. The decision of the Court of Appeals of New York was as a whole based on this thesis. Of course, the conclusion does not, of necessity, follow the premise. But it is not unnatural that the conclusion should follow in the mind of one who believes in the premise, and is imbued with a just admiration of the principles of the common law. Personally, with respect to those who have an opposite opinion, I do not believe that merely because a principle has not been recognized by the common law, it is necessarily to be regarded as opposed to fundamental ideas of right. And furthermore, I believe it can be shown that the law as developed by our courts without the aid of statutory enactments has recognized the principle that liability may be imposed without fault. These, however, are large legal questions worthy of separate treatment. 